\title{
Gender Involvement in Production, Processing and Marketing of Spice in Southeast Nigeria
}

\author{
${ }^{1}$ Peter-Onoh, C. A., ${ }^{1}$ Onoh, P. A., ${ }^{1}$ Ngwuta, A. A., ${ }^{1}$ Obiefuna, J. C., ${ }^{1}$ Akalonu, E. \\ C., ${ }^{1}$ Ekwugha, E. U. and ${ }^{2}$ Ihenacho, L. U., ${ }^{1}$ Emma-Okafor, L. C. \\ ${ }^{1}$ Federal University of Technology Owerri, Imo State \\ ${ }^{2}$ Imo Polytechnic, Umuagwo Ohaji, Owerri, Imo State
}

\begin{abstract}
Spices are those plants the products of which are made use as food adjunct to add aroma and flavor. Majority of the Nigeria population, particularly in the village depend on natural medicines derived from herbs and spices. The area of study is Southeast Nigeria, which is made up of five states: Abia, Anambra, Ebonyi, Enugu and Imo. It has a total population of 16.38 million people with about $75 \%$ or 8.78 million in rural areas, of which about $49.38 \%$ are women. A multi-stage sampling, were purposefully selected from Abia, Imo and Enugu states. This was followed by random selection of two (2) local government Areas from each of the three (3) states. The following data were collected; a) the socio- economic characteristics of the farmers, involvement in farming and marketing. Descriptive statistics: percentages and frequency were used to assess gender involvement in spice production. Results showed that women were predominately involved in spice production, processing and marketing in the study area due to culinary and medicinal importance. Most rural dwellers are women who labour day and night to sustain the family's food supply and provide extra income of the households. Women of Southeast Nigeria engage in production, processing and marketing of various kinds of spices. The production chain of these spices are within the home garden, where no extra payment is made for the land, which is one the major constraints.
\end{abstract}

Keywords: Women, production, spices, questionnaire, respondents.

\section{Introduction}

Spices are those plants the products of which are made use as food adjunct to add aroma and flavor [1]. They are used whole, ground, paste or liquid form mainly flavouring and seasonal food. Most spices increase the sheiflife of food especially the dry varieties [2].

Their health giving effects are usually indirect. They stimulate the eye as a decoration of dishes, nose and tongue and thus stimulate the flow of saliva (starch digestion) and the secretion of enzymes in the stomachintestine system (protein and fat) [1].

Uses of Spices in Southeast Nigeria

a. Some of the spices are widely consumed as pepper soup for women who put to bed as post natal cleansing of the delivery system.

b. Most of these spices have been associated with abundant bitter principle which is claim to reduce blood sugar levels, and their liquor taken as a purge for colic, stomach pains, hypertension and worm infections.

c. Majority of the population, particularly in the villages depend on natural medicine for people in the absence of modern medical facilities. Generally, each specie play a very important role in the diet, culture and custom of the the people in the area when they grow.

d. Some spices, fruits, seed, leaves and stems (vine) are used in various ways in making soup, stew, cake and other delicacies.

\section{The Role Of Women Agriculture}

In sub-Saharan Africa, women account for up to $80 \%$ of the food produced, processed, stored and marketed [3]. Yet, despite their important role in agricultural livelihoods do not always translate into increased income for the women or improved decision-making capacity [4].

Every country's development is focused mainly on the uplifting of the rural smallholder farming sector. Most people in this group are women who labour day and night to sustain the family's food supply and provide extra income to the households. In addition, they grow half of the world's food requirement [5]. Women are the invisible agricultural producers in peasant society [6]. Nearly $85 \%$ of women's labour is spent in farming [7]. Women in Ethiopia play multiple and overlapping roles, which have increasingly put pressure on their health, food security, productivity and potential contribution to improve human welfare and economic development [8]. Generally, women are considered as heads of house-holds, while all the important activities of 
women are hidden behind the man. But, the fact is that women play a significant role in food chain production, processing, storage and marketing using family labour as a whole (men, women and children).

In the present context, however, the likelihood of women equally sharing the benefits accruing from the growth of the agricultural sector in terms of economics returns, social capital and empowerment are relatively small, given the equality in status, opportunity and access to services and market knowledge between men and women.

\subsection{Women's Participation In Spices Production/Gathering}

Indigenous spices and other culinary species produced in Southeast Nigeria showing the local names, English names and edible portion consumed. The spices grow commonly in high forest areas of the South Eastern region of Nigeria, as climbers, perennial creepers, or slim shrubs and trees and are available all year round [9]). Most of these spices have been associated with abundant bitter principle which is claimed to reduce blood sugar levels, and their liquor taken as a purge for colic, stomach pains, and worm infections. It is also believed that newborn babies grow rapidly when they are fed with food made of these spices [10].

\section{a. Cultivated Spices}

Occimum basilium L (Nchuanwu), Capsicum frutescene L (Ose) are mostly cultivated spices. The crop spices are grown at the backyards or home gardens as intercrop with other vegetables and arable crops.

\section{b. Semi-Wild Spices}

Gongronema latifolium (Utazi) and Piper guineense (Uziza) are climbers and can be found beside already existing tree and shrub vegetables as Pterocarpus soyauxii (oha), Pterocarpus santalinoides (Nturukpa) etc as companion crops. These climbers are planted beside the fence (made of bamboo sticks or palm fronds), sometimes intercropped with yam or planted in kola plantation and Parkia biglobosa (Ugba/Ogiri) shrubs which are also semi-wild spices.

\section{Organic agriculture}

These women practice purely organic agriculture, by using waste/refuse collected from their compounds, poultry cages, farmyard manure, kitchen waste, etc. These organic manures are spread at the base of the crops and in the home gardens.

\section{c. Wild Spices}

Monodora myristica (Ehuru), Tetrapluera tetraptera (Oghokiriogho) and Xylopia aethiopica (Uda) are wild spices found in the forest as volunteers tree crops. T. tetraptera is a pod with quadrangular sides/wings, while Xylopia aethopica is a pod in bunches of 5-6. Both have small seeds inside the pods. At the early stages of fruiting, their pods (fruits) are usually green in colour and changes to deep dark brown at maturity. Monodora myristica is a berry like fruit and sharped like small calabash fruit. The colour is green and at physiological maturity changes to light yellow green before dropping from the tree when they are fully matured the fruits drop and gathered/picked by these women. The method of drop and pick of these wild spices will eventually affect the quality of these products and the health of the consumers, these is need for more research findings on how to conserve these spices, improve the quality standard and also avoid extinction because the forest where these spices are found are being tampered with so often because of development, like construction of roads, electricity lines, industries and estates. We have noticed that these spices are fast disappearing from the market and our environment.

Remedy

On the above reasons, the Federal University of Technology Owerri, in Imo state Nigeria, has decided to set up a study on Domestication, characterization and storage of plant genetic resources of under-utilized tropical spices in Southeast Nigeria.

\section{Processing Of Spices}

The spices are categorized into seeds, fruits, leaves and rhizomes. Some of the seed-spices are Piper guineense, Xylopia aethiopica etc. These seeds are sundried properly to reduce their moisture content to avoid moulds and decaying. To improve/increase their shelf-life, they are ground into powder and stored in small size bottle containers, jars and small size clear polytene packs.

Monodora myristica, the berry-like fruits are gathered and kept under the shed for 4-6 days to facilitate decay or fermentation. The colour will change from light brown to black, an indication of proper decay. The extracted seeds are washed and spread on a cane long tray (locally made tray with bamboo) or spread on concrete floors when dried, the hard seed coats are removed by cracking with either stone or kitchen knife. The brown nuts are fried until the colour changes to coffee colour. The fried nuts are pounded with mortar and pistle, grinding stone or ground to fine powder and stored in bottles and jars. 
Gongronema latifolium, Occimum basilium and Piper guineense leaves can be stored and consumed dry. These leafy spices are harvested, chop/cut into pieces and spread with cane long trays (locally made tray for spreading farm produce). This study aimed at the involvement of women in the production, processing and marketing of spices in Southeast Nigeria.

\section{Location Of The Study Area Women}

The area of study is Southeast Nigeria. Southeast Nigeria is made up of five states: Abia, Anambra, Ebonyi, Enugu and Imo. The area has an approximate land area of 58,214.7 sq. $\mathrm{km}$. and lies between longitude $6^{\circ} 50^{\prime}$ and $8^{\circ} 30^{\prime} \mathrm{E}$ and latitudes $4^{\circ}-30$ and $75 \mathrm{~N}$, [11]. It has a total population of 16.38 million people with about $75 \%$ or 8.78 million in rural areas, of which about $49.38 \%$ are women [12]. The occupation of the people is basically farming, combined mainly with non-farm activities in varying degrees. The people are mainly Igbo tribe of Nigeria. Some rural non-farm crafts and technologies common in the areas by the women include food and farm processing such as palm oil processing, cloth weaving and dyeing and pottery, while men are mainly involved in wine tapping, blacksmithing, wood carving and metal work. The vegetation lies within the rainforest and savannah regions of Nigeria. It has a tropical humid climate with two distinct seasons of the year.

Each season spans for about six months. Rainy season lasts from April to October and is marked by regular and consistent rainfall pattern with consequent drop in ambient temperature. The dry season covers the months of November to March and is characterized by a hot dry spell that exerts a lot of body discomfort on both man and livestock. Within the two seasons the temperature range varies from about $18^{0} \mathrm{C}$ to $34^{0} \mathrm{C}$. Tree crops are also observable landscape features of the area which play various roles in the lives and economic wellbeing of the people of the study area. A multi-stage sampling, were purposefully selected for Abia, Imo and Enugu state. This was followed by random selection of two (2) local government Areas from each of the three (3) states. Thus, Umuahia and Ikwuano, Owerri west and Ohaji/Egbema, Udi and Ezeagu Local Government Areas were selected from Abia, Imo and Enugu states respectively. Total of six (6) LGAs were involved in the study. A total of forty five (45) farmers both male and female in the two (2) LGAs of each state were sampled systematically to give a total number of one hundred and thirty five fifty (135) farmers and were used for analysis. Trained extension agents from each LGAs ADP offices administered and assisted in the distribution and collection of data through a structured questionnaire. The following data were collected; a) the socioeconomic characteristics of the farmers, involvement in farming and marketing. Descriptive statistics: percentages and frequency were used to assess gender involvement in spice production.

\section{Results And Discussion}

\section{1 Distribution of socio-economic characteristics of gender involvement in spice production}

The results of socio-economic characteristics analysis of the respondents included sex, age, marital status, family size, level of education and occupation (Table 1). The results showed that the respondents were predominantly females in the study area. This is evident as $60.0 \%$ were females relative to $40.0 \%$ mal This disagrees with the findings of [13] that observed women as major stakeholders in the provision of food. The farmers between the ages of 51- 60 years were actively involved in the farming followed by 41-50. Specifically, the ages between 51-60 were the highest proportion with 34\% followed by 41-50 (24. 4\%). The greatest percentage of users was predominately married (88. $0 \%)$ within the study area, relative to singles $(27.0 \%)$, widows $(11 \%)$ and widowers $(9.0 \%)$. The family size of majority of respondents in the range of 5-7 (34.8\%) and 0-4 (31.0\%), followed by 8-10 (22.9\%) members. Spice users are mainly married (65.18\%), this shows how important marriage institution is in Africa and signifies the possibility of more availability of family labour for farming activities. The results also showed that the highest level of education attained by majority of respondents is secondary education $(37.0 \%$ ), while primary and tertiary education is $31.0 \%$ and $20 \%$ respectively, [14] and [15] viewed formal education as means of facilitating farmers use of written information sources and increasing their knowledge and comprehension of new farm practices. Most respondents are farmers $(49.6 \%)$, followed by civil service $(25.0 \%)$ and traders $(13.0 \%)$. 
Table 1.Distribution of respondent according to socio-economic characteristics

\begin{tabular}{|c|c|c|}
\hline Variables & Freqency & Percentage \\
\hline Sex & & \\
\hline Male & 54 & 40 \\
\hline Female & 81 & 60 \\
\hline Total & 135 & 100 \\
\hline Age & & \\
\hline $31-40$ & 16 & 11.85 \\
\hline $41-50$ & 33 & 24.44 \\
\hline $51-60$ & 31 & 22.96 \\
\hline $61-70$ & 46 & 34.07 \\
\hline 70 and above & 09 & 6.68 \\
\hline Total & 135 & 100 \\
\hline Marital Status & & \\
\hline Single & 27 & 20.00 \\
\hline Married & 88 & 65.18 \\
\hline Widow & 09 & 6.67 \\
\hline Widower & 11 & 8.15 \\
\hline Total & 135 & 100 \\
\hline Family size & & \\
\hline $0-4$ & 42 & 31.11 \\
\hline $5-7$ & 47 & 34.81 \\
\hline $8-10$ & 31 & 22.96 \\
\hline 10 and above & 15 & 11.11 \\
\hline Total & 135 & 100 \\
\hline Level of Education & & \\
\hline No formal education & 15 & 11.11 \\
\hline Primary & 43 & 31.85 \\
\hline Secondary & 50 & 37.04 \\
\hline Tertiary education & 27 & 20.00 \\
\hline Total & 135 & 100 \\
\hline Occupation & & \\
\hline Farming & 67 & 49.63 \\
\hline Trading & 18 & 13.33 \\
\hline Civil service & 35 & 25.93 \\
\hline Others & 15 & 11.11 \\
\hline Total & 135 & 100 \\
\hline
\end{tabular}

Source: Field Survey, 2012.

\section{2 Distribution according to involvement of women in spice farming}

The results showed that all the respondents $(100 \%)$ use spices . However, spices are used mostly as the need arises $(88.2 \%)$, and in frequently on Daily Need $(4.4 \%)$ or rarely used as None of The Above (5.2\%). This is as a result of its versatility in the preparation of many local dishes (to stimulate change in taste, flavor, aroma) and medicine [16]. The major source of spices have been the backyard (55.0\%) followed by garden $(50 \%)$ and $10 \%$ is for both protected stands and farm respectively. Females $(85 \%)$ have been shown to be predominant owners of these spice crops while some are protected plants by male (15\%). Results from the study area indicated that 60 of the respondents reported that these spices are used as medicine, followed by 50 respondents who used them as spices. Most of these spices have been associated with abundant bitter principle which is claimed to reduce blood sugar levels, and their liquor taken as a purge for colic, stomach pains, and worm infections. It is also believed that newborn babies grow rapidly when they are fed with food made of these spices [10]. Most of the spices are sold in the market as indicated by $74.1 \%$ of the respondents and $14.8 \%$ sold in the vegetable shops. 
Table 2.Distribution of respondent according to involvement in spice production

\begin{tabular}{|c|c|c|}
\hline Variables & Freqency & Percentage \\
\hline \multicolumn{3}{|l|}{ Knowledge/Use } \\
\hline Yes & 135 & 100.0 \\
\hline No & 0 & 0 \\
\hline Total & 135 & 100 \\
\hline \multicolumn{3}{|l|}{ Freqency of Use } \\
\hline Daily & 7 & 5.0 \\
\hline Once a week & - & - \\
\hline Once in 2 wks & 8 & 5.9 \\
\hline Once in a month & - & - \\
\hline As need arise & 120 & 88.9 \\
\hline Total & 135 & 100 \\
\hline \multicolumn{3}{|l|}{ Source } \\
\hline Backyard & 55 & 40.7 \\
\hline Forest & 10 & 7.4 \\
\hline Farm & 10 & 7.4 \\
\hline Garden & 50 & 37.0 \\
\hline Protected farm & 10 & 7.4 \\
\hline Total & 135 & 100 \\
\hline \multicolumn{3}{|l|}{ Purpose of Use } \\
\hline As spice & 50 & 37.0 \\
\hline Medicinal & 60 & 44.4 \\
\hline All of the above & 10 & 07.4 \\
\hline Any of the above & 15 & 11.0 \\
\hline Total & 135 & 100 \\
\hline \multicolumn{3}{|l|}{ Ownership } \\
\hline Male & 20 & 14.8 \\
\hline Female & 115 & 85.19 \\
\hline None of the above & 00 & 00 \\
\hline Total & 135 & 100 \\
\hline \multicolumn{3}{|l|}{ Marketing channels } \\
\hline Market & 100 & 74.1 \\
\hline Vegetable shops & 20 & 14.8 \\
\hline Restaurant & 10 & 7.4 \\
\hline All of the above & 5 & 3.7 \\
\hline Total & 135 & 100 \\
\hline
\end{tabular}

Source: Field Survey, 2012.

\section{3 Marketing}

The markets hold on specific days according to Igbo calendar which is Eke, Nkwo, Orie and Afor. For the fact that people from the study area is predominantly Christians, any market that falls on a Sunday will rather be on Saturday before the Sunday. Each day of the calendar is attached to the name of the town where the market is located. Within Owerri West and Ohaji/Egbema local government areas in Imo state, these spices are found in Eke-Oforola, Afor-Obinze, Orie-Umuguma and Afor-Eziobodo while Orie-Umuokanne, NkwoMgbirichi and Afor-Umuagwo respectively. In Enugu state, Nkwo Ezeagu Obinofia, Nkwo-Agana Olo and Afor-Oghe markets are found in Ezeagu local government while Nkwo-Agu, Orie-Agu and Orie-Abor markets are in Udi local government. Within Umuahia South and Ikwuano LGAs in Abia state, the spices are found in Aforukwu-Olokoro, Afor-Ibeji Old-Umuahia, Ubakaia etc. others are in Nkwo Ndi Oru, Ariam-Osaka, Oboro, Oloko markets. The women harvest the leafy spices in the evening before the market day so that the spices will 
be fresh. These women leave their houses for the market early in the morning each market day. Both the processed, unprocessed and fresh spices are marketed. They market their produce mainly on whole sale bases and in rare occassions retail some. They package in various units and according to quality. Some of these women also supply to hotels, restaurants and supermarkets.

\subsection{Advantages Of Cropping Spices For Women}

a. These women do not have their own land by making use of their backyard, fences, homegarden and existing trees in their husbands' compound, the issue of land problem is settles and no payment is made for the land.

b. The income generated help in the improvement of the family livelihood.

c. They do not spend so much in labour because every member of the family participates in the production.

d. The use of waste from the compound as organic fertilizer e.g poultry droppings, farm yard manure and kitchen wastes saves money for them.

e. The women do not go far to attend to their crops and at times engage in other farming activities.

\section{2 Constraints To Spice Production For Women}

Expanding production of spices is often hindered by different factors such as lack of market access, market information, pest inappropriate management, input supply, credit and extension services moreover,[17] reported that female-headed households have less access to state and rented land them male-headed households. Access to credit facilities is another constraint, without it, women cannot obtain input and use modern technology storage remains a big problem for the whole agricultural sector. Storage limits the horizon of spices marketing; outreach is restricted by factors like distance and time. If these could be brought under control, preand post harvest losses would be reduced significantly. Thus, women should be provided training opportunities and access to information on how to produce and supply safe products of spices in the markets.

\section{Conclusion}

Studies on spices have been mostly on their exciting flavors and aromas, medicinal values and flavoring agents. The financial benefits from spices production improve their standard of living and also increase consumption by themselves and their family members. These spices are said to be therapeutically useful in the management of convulsion, leprosy, stomachache, inflammation and/or rheumatoid pains, cough and loss of appetite [18].

\section{Reference}

[1]. Scully, Terrance. 1995. The art of cookery in the middle Ages. Ipaswich: boydell press. ISBN 0-85115-611-8. Pg.9-11.

[2]. Weiss, E. A. 2002. Spice Oxon CABI. Publishing. Pp 102-103. ISBN 08519960501.

[3]. FAO (Food and Agriculture Organization). 2007. Gender equality, Ft//ftpFAO/docrep/FAO/011/0765e

[4]. Elson, D. 1990. Labour markets as gendered institution. Equality, efficiency and empowerment issues, world development, 27 (3) 611-627.

[5]. FAO (Food and Agriculture Organization). 1993. Agricultural Extension and farm women in the 1980's. FAO Rome.

[6]. Ellis, F. 1993. Peasant economics farm houses and Agraian development $2^{\text {nd }}$ ed. Cambrigde.

[7]. Yeshi, C. 1997. The need for incorporating gender factors in crop science society, Uganda.

[8]. Senait, S. 2002. Gender issues in food security in Eithiopia. Reflecton, No. 7, Panos. Addis Abbaba, Ethiopia.

[9]. Sofowara A 1993. Medicinal plants and Traditional medicine in Africa. Spectrum Books Ltd, Ibadan, Nigeria. p. 289

[10]. Roger G.P.D (2002). Encyclopedia of Medicinal Plants. Vol. 1. Education and Health, Library Editorial Saleliz S.I. Spain, pp. 153154 .

[11]. Mamman A. B., Oyebanji, J. O. And Pters S. W. (eds). 2000. Nigeria: A people United. A future Assured, Vol. 2 Survey of States. Federal Ministry of Information. Abuja.

[12]. National population census, 2007. Federal Government Printer Lagos Nigeria.

[13]. Suleiman, A. 2004. Smallholder supply response and gender in Ethiopia: A profit function analysis, Dept. of Economics University of Sheldffield, United Kingdom.

[14]. Ani, A. O., Ogunnika, O. and Ifa, S. S. 2004. Relationship between socio-economic characteristics of Rural women farmers and their adoption of farm technologies in South Ebonyi state Nigeria. International journal of Agriculture and Biology; $\mathrm{Http} / \mathrm{www} . \mathrm{ijab}$.org.

[15]. Asiabaka, C. C. 2002. Agricultural Extension: A handbook for Development Practitiones. Molsyfem united services Ahoda, River State pp 112-120.

[16]. Rogers, E. M. 1995. Diffusion of Innovation. $4^{\text {th }}$ Edition. Free press New York.

[17]. Edeoga, H. O. and Gomina A. 2000). Nutritional values of some noncomventional leafy vegetables of Nigeria. J. Econ. Taxon. Bot. 24:7-13

[18]. Gills, L. S. 1992. Ethnomedical uses of plants in Nigeria. University of Benin press, Nigeria. P. 276. 